\title{
WEIGHT LOSS AND NUTRITIONAL ANEMIA IN PATIENTS SUBMITTED TO ROUX-EN-Y GASTRIC BYPASS ON USE OF VITAMIN AND MINERAL SUPPLEMENTATION
}

\author{
Perda ponderal e presença de anemias carenciais em pacientes submetidos à bypass gástrico em Y-de-Roux em uso de \\ suplementação de vitaminas e minerais
}

\begin{abstract}
Natalia Maria Coutinho Pinheiro de Jesus RAMOS$^{1}$, Fernanda Cristina Carvalho Mattos MAGNO ${ }^{1,2}$, Larissa COHEN $^{1}$, Eliane Lopes ROSADO' ${ }^{1}$, João Régis Ivar CARNEIRO ${ }^{2}$
\end{abstract}

From¹Instituto de Nutrição Josué de Castro, Centro de Ciências da Saúde, Universidade Federal do Rio de Janeiro ('Nutrition Institute Josué de Castro, Health Sciences Center of Federal University of Rio de Janeiro) and ${ }^{2}$ Programa de Cirurgia Bariátrica do Hospital Universitário Clementino Fraga Filho, Universidade Federal do Rio de Janeiro ('Bariatric Surgery Program of Academic Hospital Clementino Fraga Filho, Federal University of Rio de Janeiro), Rio de Janeiro, RJ, Brazil.

HEADINGS - Bariatric surgery. Deficiencies diseases. Weight loss. Anemia.
ABSTRACT - Background: Obesity is a chronic disease with high growth in population and bariatric surgery is currently considered the most effective treatment for weight reduction; on the other hand, nutritional deficiencies are observed after this procedure. Aim: To analyze weight loss progression and nutritional anemia in patients submitted to Roux-en-Y gastric bypass on use of vitamin and mineral supplementation. Methods: Retrospective analysis of 137 patients of both sexes, aged between 18-60 years, using supplemental multivitamins and minerals, were included; personal information, anthropometric and laboratory data in the preoperative, 12, 24, 36 and 48 months postoperatively were collected. Results: Postoperatively, in both sexes, occurred weight loss compared to the pre-operative weight gain at 48 months and maintenance of body mass index. There was a decrease in the percentage of excess weight loss at 48 months postoperatively compared to the time of 12,24 and 36 months in men and decreased at 48 postoperative months compared to the time of 24 months in females. There was a decreased in serum ferritin in both sexes and increased serum iron at 48 months postoperatively in males. There was a decreased in vitamin B12 and folic acid increased serum at 48 postoperative months in females. Conclusions: Surgical treatment was effective for reducing weight, body mass index reduction and achievement of success in the late postoperative period along with multivitamin and mineral supplementation on prevention of serious nutritional deficiencies and anemia.

\section{Correspondence:}

Natalia Maria Coutinho Pinheiro de Jesus Ramos E-mail: nati.nutriclin@gmail.com

Financial source: none

Conflicts of interest: none

Received for publication: 21/08/2014 Accepted for publication: 27/11/2014

DESCRTORES - Cirurgia bariátrica. Deficiências nutricionais. Perda de peso. Anemia.
RESUMO - Racional: A obesidade é doença crônica com elevado crescimento na população. A cirurgia bariátrica é considerada o tratamento mais efetivo para redução de peso; por outro lado, deficiências nutricionais são observadas após esse procedimento. Objetivo: Avaliar a evolução da perda ponderal e a presença de anemias carenciais em pacientes submetidos ao bypass gástrico em Y-de-Roux em uso de suplementação de vitaminas e minerais. Métodos: Análise retrospectiva de 137 pacientes de ambos os sexos, com idade entre 18-60 anos, em uso de suplementação de polivitaminas e minerais incluindo informações pessoais, dados antropométricos e laboratoriais nos períodos pré-operatório, 12, 24, 36 e 48 meses de pósoperatório. Resultados: No pós-operatório, em ambos os sexos, ocorreu perda de peso em relação ao pré-operatório, ganho de peso aos 48 meses e manutenção do índice de massa corporal. Houve diminuição do percentual de perda de excesso de peso aos 48 meses pósoperatórios comparado com os tempos 12, 24 e 36 meses em homens e diminuição aos 48 meses pós-operatórios em relação aos 24 meses no sexo feminino. Houve diminuição da ferritina sérica em ambos os sexos e aumento do ferro sérico aos 48 meses pós-operatório no sexo masculino. Houve diminuição da vitamina B12 e aumento do ácido fólico séricos aos 48 meses do pós-operatório no sexo feminino. Conclusões: $O$ tratamento cirúrgico mostrouse eficaz para redução de peso, redução do índice de massa corporal e alcance do sucesso no pós-operatório tardio juntamente com a suplementação de polivitamínico e minerais na prevenção de deficiências nutricionais importantes e anemias.

\section{INTRODUCTION}

$\mathrm{O}$ besity is a chronic disease, with high increase in the population and World Health Organization surveys project an even worse scenario for the next years, estimating that, in 2015, 2.3 billion people will be overweight and 700 million will be obese worldwide ${ }^{26}$

The Roux-en-Y gastric bypass (RYGB) is the most frequently used mixed procedure and despite the results of weight loss being proven and well documented, it has been observed some level of weight recovery from two to three years after the surgery $7,14,21$. The weight recovery after the surgery reinforces the concept that obesity is a chronic, progressive and incurable disease, and it needs specific treatment even after the surgery $\mathrm{y}^{4,15}$.

The RYGB is a restrictive and malabsorptive surgery, which makes more common the worsening or appearance of nutritional deficiencies in the first six 
months of the post-operative period (PO), such as protein malnutrition, iron deficiency, vitamin B12, folic acid, vitamins $A, E$ and $D$ and minerals like copper and zinc ${ }^{30}$.

Such deficiencies may lead to future nutritional complications, like anemia that occur due to gastric resection, mainly when the surgery is done through $\mathrm{RYGB}^{15}$. Iron deficiencies occur in $50 \%$ of the patients and they are precursor of anemia and consequently, the serum levels of transferrin may decrease even if hemoglobin is in normal levels, due to inefficient in iron absorption ${ }^{1}$.

Serum ferritin may have a smaller value in patients submitted to RYGB due to depletion of the iron stocks and copper deficiency, leading to normocytic anemia ${ }^{1}$. The main common cause of vitamin B12 deficiency is pernicious and macrocytic anemia, as well as folic acid deficiency. Besides megaloblastic anemia, the patient may show leukopenia, glossitis and high levels of homocysteine ${ }^{24}$.

The present study aimed to assess the weight loss evolution and identify the occurrence of anemia in patients submitted to RYGB in use of vitamins and minerals supplementation.

\section{METHODS}

Information about the patients were obtained through medical and nutrition records from a private clinic located in Rio de Janeiro. The study protocol was approved by the Research Ethics Committee from Hospital Universitário Clementino Fraga Filho, under the number 176/09.

One hundred thirty seven patients from both genders, aging between 18-60 years, submitted to RYGB, in use of polivitamins and minerals supplementation and periodic nutritional counseling were included. Patients who had physiological complications post operatively that caused laboratorial alteration, pregnancy, patients that reside outside Rio de Janeiro, the deceased and those who did not continue the nutritional treatment at least for 24 months after the procedure, were excluded from the study.

During the survey on medical records, there were collected variables such as name, age, gender, postoperative values and $12,24,36$ and 48 months of postoperative biochemical examinations (red blood cells, hemoglobin, hematocrit, iron, ferritin, vitamin B12 and folic acid). Anthropometric data body weight and height) was analyzed from: 1) body mass index (BMI in $\mathrm{kg} / \mathrm{m}^{2}$ ), obtained dividing the body mass by the height's square; 2) overweight in the procedure (in $\mathrm{kg}$ ), i.e., the difference of the pre-operative weight from the ideal weight; 3 ) weight loss (in $\mathrm{kg}$ ), i.e., the difference of the pre-operative weight from the current weight; 4) percentage of excess weight loss (\%EWL), i.e., the difference of the weight loss percentage from the excess weight.

The reference values of the biochemical examinations, used as minimum scores were: values between 4,3-5,9 $\mathrm{x}$ $10^{6} / \mathrm{mm}^{3}$ of red blood cells for men and $3,5-5,9 \times 10^{6} / \mathrm{mm}^{3}$ for women; hemoglobin between $14-17 \mathrm{~g} / \mathrm{dl}$ for men and $12-15 \mathrm{~g} / \mathrm{dl}$ for women; hematocrit between $42 \%-52 \%$ for men and 35\%-47\% for women; iron between $60-170 \mathrm{mg} /$ dl for men and 50-160 mg/dl for women; ferritin between $36-262 \mathrm{mcg} / \mathrm{dl}$ for women and $10-64 \mathrm{mcg} / \mathrm{dl}$ for women; $\geq 250 \mathrm{mg} / \mathrm{dl}$ vitamin B12 and $6-20 \mathrm{mcg} / \mathrm{dl}$ of folic acid for both genders.

A descriptive analysis of the qualitative data was performed. The quantitative data was expressed as average and confidence interval at $95 \%$. Data normality was assessed by the Kolmogorov-Smirnov test. The ttest was performed for comparison of the laboratorial variables, in both genders, pre-operatively and 48 months post-operatively, and one-way ANOVA multivariate for comparison of the anthropometric variables between the pre-operative period, 12, 24, 36 and 48 months postoperatively, being considered as significant two-tailed $p$ value $<0,05$. The Statistical Package for the Social Sciences (SPSS) was used, version 21.0 for Windows.

\section{RESULTS}

Table 1 shows the distribution of the qualitative variables. Of the 137 patients, females outnumbered males and preoperatively, in both genders BMI showed above $40 \mathrm{~kg} / \mathrm{m}^{2}$.

TABLE 1 - Characteristics of the studied population

\begin{tabular}{|c|c|c|c|c|}
\hline \multicolumn{3}{|c|}{ Variables } & $\%$ & (n) \\
\hline \multirow{2}{*}{ Gender } & \multicolumn{2}{|c|}{ Male } & 18 & 24 \\
\hline & \multicolumn{2}{|c|}{ Female } & 82 & 113 \\
\hline \multirow{6}{*}{ Age (years) } & \multirow{3}{*}{ Male } & $19-30$ & 25 & 6 \\
\hline & & $31-44$ & 63 & 15 \\
\hline & & $45-60$ & 12 & 3 \\
\hline & \multirow{3}{*}{ Female } & $19-30$ & 26 & 29 \\
\hline & & $31-44$ & 38 & 43 \\
\hline & & $45-60$ & 36 & 41 \\
\hline \multirow{4}{*}{ BMI $\mathrm{kg} / \mathrm{m}^{2}$} & \multirow{2}{*}{ Male } & $35-39,99$ & 8 & 2 \\
\hline & & $\geq 40$ & 92 & 22 \\
\hline & \multirow{2}{*}{ Female } & $35-39,99$ & 15 & 17 \\
\hline & & $\geq 40$ & 85 & 96 \\
\hline
\end{tabular}

$\mathrm{BMI}=$ body mass index; $\mathrm{n}=$ number of patients

Table 2 shows that in both genders weight loss occurred in the whole $\mathrm{PO}$ period in relation to the preoperative. Post-operatively, the anthropometric variables at 24, 36 and 48 months were compared with a 12-month period and it was found weight maintenance until 36 months in both genders. In males it was observed weight gain in 48 months when compared to 12, 24 and 36 months, and in females, it was observed weight gain in 48 months when compared to 24 months. It was verified BMI maintenance in the whole $\mathrm{PO}$ period in both genders. In men, \%EWL decreased in 48 months compared to 12,24 and 36 post-operative months, and in women, 48 months in relation to 24 months.

TABLE 2 - Weight evaluation pre- and post-operatively

\begin{tabular}{|c|c|c|c|c|c|}
\hline \multicolumn{6}{|c|}{ Male } \\
\hline Variables & PreOPWeight & P012M & PO24M & PO36M & PO48M \\
\hline Weight (kg) & $124,6 \pm 15,4^{\text {bcd }}$ & $89,9 \pm 11,3^{a}$ & $88,5 \pm 11,9^{a}$ & $89,6 \pm 13,1^{a}$ & $92,0 \pm 12,8^{\text {abcd }}$ \\
\hline $\mathrm{BMI}\left(\mathrm{kg} / \mathrm{m}^{2}\right)$ & $45,5 \pm 5,1^{\text {bcd }}$ & $28,5 \pm 3,41$ & $28,0 \pm 3,27$ & $28,4 \pm 3,7$ & $29,1 \pm 3,5^{1}$ \\
\hline EWL (\%) & -- & $84,5 \pm 15,6$ & $85,8 \pm 16,2$ & $84,0 \pm 18,3$ & $80,0 \pm 16,7^{\mathrm{bcd}}$ \\
\hline \multicolumn{6}{|c|}{ Female } \\
\hline Variables & Pre-OPWeight & PO12M & PO24M & PO36M & PO48M \\
\hline Weight (kg) & $118,1 \pm 16,6^{\text {bcd }}$ & $76,6 \pm 13,5^{a}$ & $73,0 \pm 11,5^{a}$ & $74,3 \pm 12,5^{a}$ & $76,0 \pm 12,6^{\mathrm{ac}}$ \\
\hline $\operatorname{BMI}\left(\mathrm{kg} / \mathrm{m}^{2}\right)$ & $44,9 \pm 5,8^{\text {bcd }}$ & $29,2 \pm 4,8^{a}$ & $27,8 \pm 4,2^{a}$ & $28,3 \pm 4,5^{a}$ & $28,9 \pm 4,5^{a}$ \\
\hline EWL (\%) & -- & $82,3 \pm 20,4$ & $88,1 \pm 18,8$ & $85,4 \pm 20,1$ & $81,7 \pm 20,4^{c}$ \\
\hline
\end{tabular}

$\mathrm{BMI}=$ body mass index; Pre- $\mathrm{OP}=$ pre-operative; $\mathrm{PO}=$ post-operative weight $E W L=$ excess weight loss; ANOVA: ${ }^{a} p<0.05$ vs. pre-operative, ${ }^{b} p<0.05$ vs. 12 post-operative months ${ }^{c} p<0.05$ vs. 24 post-operative months, ${ }^{d} p<0.05$ vs. 36 post-operative months.

Table 3 shows serum ferritin reduction and serum iron increase in 48 months $\mathrm{PO}$, in males. Serum ferritin and vitamin B12 decreased and serum folic acid increased in 48 months $\mathrm{PO}$, in females. 
TABLE 3 - Evaluation of the pre- and post-operative biochemical parameters

\begin{tabular}{|c|c|c|c|c|c|}
\hline \multicolumn{5}{c}{ Male } \\
\hline Paramaters & Pre-OP & PO12M & PO24M & PO36M & PO48M \\
\hline Redbloodcells & $4,7 \pm 0,4$ & $4,5 \pm 0,3$ & $4,5 \pm 0,3$ & $4,5 \pm 0,5$ & $4,6 \pm 0,3$ \\
\hline Hemoglobin & $13,5 \pm 1,1$ & $13,1 \pm 0,9$ & $13,2 \pm 1,0$ & $12,5 \pm 1,4$ & $13,1 \pm 0,9$ \\
\hline Hematocit & $40,8 \pm 3,2$ & $39,9 \pm 2,9$ & $40,0 \pm 3,1$ & $38,3 \pm 3,7$ & $39,5 \pm 2,2$ \\
\hline Iron & $79,0 \pm 24,0$ & $97,5 \pm 29,5$ & $99,8 \pm 30,7$ & $88,2 \pm 37,2$ & $101,1 \pm 36,2^{*}$ \\
\hline Fenitin & $130,2 \pm 61,1$ & $108,4 \pm 121,2$ & $87,7 \pm 114,6$ & $29,8 \pm 35,6$ & $29,9 \pm 37,5^{*}$ \\
\hline Vitamin B12 & $464,0 \pm 140,6$ & $373,8 \pm 148,3$ & $317,8 \pm 163,7$ & $401,4 \pm 352,0$ & $354,4 \pm 186,6$ \\
\hline Folic Acid & $8,6 \pm 4,2$ & $12,3 \pm 4,9$ & $11,6 \pm 4,1$ & $12,1 \pm 3,7$ & $13,4 \pm 4,6$ \\
\hline & \multicolumn{5}{|c|}{ Female } \\
\hline Parameters & Pre-OP & PO12M & PO24M & PO36M & PO48M \\
\hline Redbloodcells & $4,6 \pm 0,5$ & $4,4 \pm 0,4$ & $4,3 \pm 0,4$ & $4,3 \pm 0,4$ & $4,3 \pm 0,4$ \\
\hline Hemoglobin & $13,3 \pm 1,3$ & $12,9 \pm 1,2$ & $12,3 \pm 1,5$ & $12,2 \pm 1,5$ & $12,3 \pm 1,3$ \\
\hline Hematocit & $40,0 \pm 4,7$ & $39,1 \pm 3,6$ & $37,8 \pm 3,3$ & $37,5 \pm 4,2$ & $37,9 \pm 3,2$ \\
\hline Iron & $78,5 \pm 18,6$ & $89,2 \pm 33,6$ & $91,1 \pm 36,8$ & $87,8 \pm 38,7$ & $90,6 \pm 41,1$ \\
\hline Fenitin & $72,0 \pm 57,0$ & $61,5 \pm 50,6$ & $43,9 \pm 45,0$ & $36,4 \pm 41,3$ & $29,0 \pm 25,8^{*}$ \\
\hline Vitamin B12 & $512,5 \pm 561,5$ & $395,6 \pm 247,0$ & $391,5 \pm 212,9$ & $351,3 \pm 177,1$ & $395,8 \pm 220,3^{*}$ \\
\hline Folic Acid & $10,0 \pm 9,9$ & $12,7 \pm 5,0$ & $14,6 \pm 12,7$ & $12,6 \pm 4,6$ & $15,4 \pm 5, *^{*}$ \\
\hline
\end{tabular}

$\mathrm{BMI}=$ body mass index; Pre-OP=pre-operative; $\mathrm{PO}=$ post-operative; $\mathrm{EWL}=$ excess weight loss; "Student's paired $t$-test $\mathrm{p}<0.05$ Pre-OP vs. PO48M.

\section{DISCUSSION}

The pre-operative dietary approach follows the general recommendations of hypocaloric diet, which is the standard for obese patients, in order to promote weight loss or maintenance, and prepare them to the changes that will occur post-operatively ${ }^{27}$. Cases of anemia may occur in weeks or months after RYGB, resulting in exhaustion of several vitamins and trace elements due to achlorhydria, intrinsic factor reduction, peptic ulcers, bleeding, menstruation, inflammation induced by erythropoietic response and malabsorption 6,16

The pre-operative anemia is associated to an increase in post-operative mortality, resulting in a reduced quality of life post-operatively, while anemia's preventive healthcare has generated better life conditions to postoperated patients ${ }^{18}$. Weight loss after RYGB is related to eating reduction, followed by changes in dietary pattern of patients and malabsorption of nutrients ${ }^{8,16}$

The present study showed that weight loss and weight maintenance happened in both genders, with weight recovery in 48 months post-operatively. Accessed data corroborates the study of Skroubis et al. ${ }^{25}$, which evaluated the weight loss of 79 patients, males and females, submitted to RYGB and found body weight maintenance of $60 \pm 17 \mathrm{~kg}$ until 36 months postoperatively. A retrospective analysis of the body weight evolution performed by Novais et al. ${ }^{19}$, with 141 operated women found that the lowest weight was reached between the first and third year post-operatively and body weight recovery in 48 months post-operatively ${ }^{19}$.

Although there is controversy about the use of \%EWL as a tool of data expression, it has been widely used as a standard for analysis of the procedure results, classifying as successful those surgical treatments with a \%EWL higher than $50 \%{ }^{10}$. Several studies use it as a success evaluation tool during the post-operative period. Accordingly, the \%EWL values of Magro et al. ${ }^{14}$ were $69 \%$, Pories $^{21} 58 \%$, Capella e Capella $57 \%$, White et al. ${ }^{29} 87 \%$, Beleli et al. ${ }^{2} 67,4 \%$ and Valezi et al. ${ }^{28} 71 \%$, Faria, Faria e Cardeal ${ }^{12}$ 65\%.

Similar data were found in the present study and despite the weight recovery, patients of both genders kept in $80 \% \% \mathrm{EWL}$, considered a good result compared to the previously cited studies.

Another evaluation and classification method for PO success proposed by Reinhold ${ }^{22}$, modified by Christou et al. ${ }^{7}$, is performed according to BMI results, considering $\mathrm{BMI}<30 \mathrm{~kg} / \mathrm{m}^{2}$ an excellent result, between $30-35 \mathrm{~kg} / \mathrm{m}^{2}$ a good result and $>35 \mathrm{~kg} / \mathrm{m}^{2}$ a failure ${ }^{7,22}$. In the present research, regarding the classification of the $\mathrm{PO}$ success, patients showed an excellent result $\left(B M I<30 \mathrm{~kg} / \mathrm{m}^{2}\right)$ in 48 months.

Despite the calorie intake increasing progressively during the PO period, a subgroup of patients suffered nutritional deficiencies; thence the importance of longterm nutritional counseling ${ }^{23}$.

A study of Moreira et al. ${ }^{17}$, with 37 patients, found reduction of hemoglobin and hematocrit $\mathrm{PO}$. Coupaye et al. ${ }^{9}$, analyzed 110 patients and verified that the hemoglobin concentrations were positively correlated with iron and serum transferrin, and also identified normal values in patients that received multivitamins after bariatric surgery. On the other hand, Blume et al. ${ }^{3}$ identified anemia in 33,5\% of the studied population preoperatively and PO diminution of hemoglobin, hematocrit and iron, even with supplementation. Although patients presented hematocrit and hemoglobin below the reference values, since the pre-operative period, the levels didn't change PO.

The pathophysiology of iron deficiency is related to the intake of heme iron and the acidic environment in the stomach being, perhaps, the most common and the oldest nutritional deficiency recurrent after the bariatric surgery, occurring up to $12-47 \%$ of the patients, although often asymptomatic, it may lead to anemia and fatigue ${ }^{13,30}$

Serum iron in this sample was kept in normal values from the pre- to the post-operative periods, with an increase in 48 months. Studies of Skroubis et al..$^{25}$ and Costa et al. 8 , observed reduction of serum iron, but no reduction of serum ferritin.

The literature suggests a post-operative ferritin monitoring, keeping levels above $40 \mathrm{mcg} / \mathrm{dl}^{20}$. Ferritin plays a fundamental role in the body, storing iron, but high levels of ferritin are related to inflammatory processes ${ }^{6,18}$. In the present study, ferritin was normal pre-operatively, but post-operatively, both men and women showed low levels of ferritin.

In patients subjected to RYGB, several factors led to vitamin B12 deficiency, including limited intake of animal proteins, reduction of gastric secretions that impairs proteolytic cleavage of vitamin and inappropriate secretion of intrinsic factor ${ }^{6,12}$. Folic acid deficiency, despite not being widely published, may occur in patients subjected to bariatric surgery, as demonstrated by a prospective study with RYGB patients that found 38\% of folic acid deficiency ${ }^{24}$. The prevalence of folic acid deficiency pre-operatively in up to $54 \%$ was observed in international studies before the bariatric surgery ${ }^{30}$. Other similar studies haven't found vitamin B12 and folic acid deficiencies, and authors suggests that the non-deficiency of those specific micronutrients can be explained by the fact that some foods are fortified with folic acid, vitamin B12 storages take many years to deplete and due to high doses of multivitamin and mineral supplementation, especially vitamin B12 and folic acid ${ }^{6}$.

Although there was a decrease of vitamin B12 and folic acid in females, the values are within the reference standards. In males there was no alteration in the levels of vitamin B12 and folic acid.

It was observed that post-operatively the 
supplementary feeding was probably a contributing factor to reduce micronutrient deficiencies, making necessary the maintenance of oral supplementation and nutritional counseling in order to avoid nutritional deficiencies in the late post-operative period.

\section{CONCLUSIONS}

Surgical treatment was effective for weight reduction, body mass index reduction and achieving success in the late post-operative period, along with multivitamin and mineral supplementation, in the prevention of important nutritional deficiencies and anemia.

\section{REFERENCES}

1. Baretta GAP, Marchesini JB, Marchesini JCD, Brenner S, Sanches MER. Anemia pós-cirurgia bariátrica: as causas nem sempre são relacionadas à cirurgia. Arq Bras Cir Dig. 2008; 21(2):95-7.

2. Beleli CA, Filho AC, Silva RM, Camargo MA, Scopin DR. Fatores preditivos na perda ponderal de pacientes submetidos ao bypass gástrico em y de roux. BMI. 2011 Fev; 1(1): 27-30.

3. Blume CA, Boni CC, Casagrande DS, Rizzolli J, Padoin AV, Mottin CC. Nutritional profile of patients before and after Roux-en-Y Gastric Bypass: 3-year follow-up. Obes Surg. 2012 Nov; 22(11): 1676-85. doi: 10.1007/s11695-012-0696-y.

4. Brolin RE, Cody RP. Adding malabsorption for weight loss failure after gastric bypass. Surg Endosc. 2007 Set; 21(11): 1924-26. doi: 10.1007/s00464-007-9542-z.

5. Capella RF, Capella JF. Reducing early technical complications in gastric bypass surgery. Obes Surg. 1997 Abr; 7(2): 149-56. doi: 10.1381/096089297765556060.

6. Chen M, Krishnamurthy A, Mohamed AR, Green R. Hematological disorders following gastric bypass surgery: emerging concepts of the interplay between nutritional deficiency and inflammation. Biom Res Int. 2013 Jul; 2013(205467): 1-8. doi: 10.1155/2013/205467.

7. Christou NV, Look D, Maclean LD. Weight gain after short- and long-limb gastric bypass in patients followed for longer than 10 years. Ann Surg. 2006 Nov; 244(5): 734-40. doi: 10.1097/01. sla.0000217592.04061.d5.

8. Costa LL, Valezi AC, Matsuo T, Dichi I, Dichi JB. Repercussão da perda de peso sobre parâmetros nutricionais e metabólicos de pacientes obesos graves após um ano de gastroplastia em Y-de-Roux. Rev Col Bras Cir. [periódico na Internet] 2010; 37(2). Disponível em URL: http://www.scielo.br/rcbc. doi: 10.1590/ s010069912010000200005.

9. Coupaye M, Puchaux K, Bogard C, Msika S, Jouet P, Clerici C, et al. Nutritional consequences of adjustable gastric banding and gastric bypass: a 1-year prospective study. Res Art. 2008 Jun; 19(1): 56-65. doi: 10.1007/s11695-008-9571-2

10.Deitel M, Greenstein RJ. Recommendations for reporting weight loss. Obes Surg. 2003 Abr; 139(2): 159-60. doi: 10.1381/096089203764467117.

11. Faria SL, Faria OP, Cardeal MA. Comparação da perda de peso, consumo alimentar e frequência de vômitos entre pacientes do bypass gástrico em y-de-roux com e sem colocação de anel de contenção. Arq Bras Cir Dig. 2014 Mai; 27 (Suppl 1): S 43-46. doi: 10.1590/s0102-6720201400s100011.
12.John S, Hoegerl C. Nutritional deficiencies after gastric bypass surgery. J Am Osteopath Assoc. 2009 Nov; 109(11): 601-4.

13. Leiro LS, Melendez-Araújo MS. Adequação de micronutrientes da dieta de mulheres após um ano de bypass gástrico. Arq Bras Cir Dig. 2014 Mai; 27 (Suppl 1): S 21-25. doi: 10.1590/s01026720201400 s100006.

14. Magro DO, Geloneze B, Delfini R, Pareja BC, Callejas F, Pareja JC. Long-term weight regain after gastric bypass: a 5 -year prospective study. Obes Surg. 2008 Abr; 18(6): 648-51. doi: 10.1007/s11695007-9265-1.

15. Malinowski SS. Nutritional and metabolic complications of bariatric surgery. Am J Med Sci. 2006 Abr; 331(4): 219-25.

16. Marinella MA. Anemia following roux-en-y surgery for morbid obesity: a review. South Med J. 2008 Out; 101(10): 1024-31.

17. Moreira MA, Silva AS, Araújo CMS, Nascimento CCC. Avaliação clínico-nutricional de obesos submetidos ago bypass gastric em y de roux. Acta Gastroenterol Latinoam. 2010 Set; 40(3): 244-50.

18. Muñoz M, Botella-Romero F, Gómez-Ramírez S, Campos A, GarcíaErce A. Iron deficiency and anaemia in bariatric surgical patients: causes, diagnosis and proper management. Nutr Hosp. 2009 Dez; 24(6): 640-54. doi: 10.3305/nh.2009.24.6.4547.

19. Novais PFS, Junior IR, Leite CVS, Oliveira MRM. Evolução e classificação do peso corporal em relação aos resultados da cirurgia bariátrica-derivação gastric em y de roux. Arq Bras Endocrinol Metab. 2010 Mar; 54(3): 303-10.

20. Pedrosa IV, Burgos MGPA, Souza NC, Morais CN. Aspectos nutricionais em obesos antes e após a cirurgia bariátrica. Rev Col Bras. 2009 Jan; 36(4): 316-22.

21. Pories WJ. Bariatric surgery: risks and rewards. J Clin Endocrino Metab. 2008 Nov; 93(11 Suppl 1): S89-96.

22. Reinhold RB. Critical analysis of long-term weight loss following gastric bypass. Surg Gynecol. 1982 Set; 155(3): 385-94.

23. Sarwer DB, Dilks RJ, West-Smith L. Dietary intake and eating behavior after bariatric surgery: threats to weight loss maintenance and strategies for success. Surg Obes Relat Dis. 2011 Out; 7(5): 644-51. doi: 10.1016/j.soard.2011.06.016.

24. Shankar P, Boylan M, Sriram K. Micronutrient deficiencies after bariatric surgery. Nutr. 2010 Dez; 26: 1031-37. doi: 10.1016/j. nut.2009.12.003

25. Skroubis G, Sakellaropoulos G, Pouggouras K, Mead N, Nikiforidis G, Kalfarentzos F. Comparison of nutritional deficiencies after roux-en-y gastric bypass and after biliopancreatic diversion with roux-en-y gastric bypass. Obes Surg. 2002 Ago; 12(4): 551-58. doi: 10.1381/096089202762252334.

26. Sociedade Brasileira de Cirurgia Bariátrica e Metabólica. [online]. São Paulo, Brasil; 2013. [capturado 18 out. 2013] Disponível em: http://www.sbcb.org.br/obesidade.php?menu=0.

27. Valentino D, Sriram K, Shankar P. Update on micronutrients in bariatric surgery. Curr Opin Clin Nutr Metab Care. 2011 Nov; 14(6): 635-41. doi: 10.1097/MCO.0b013e32834b3355.

28. Valezi AC, Junior JM, Menezes MA, Brito EM, Souza JCL. Evolução ponderal oito anos após a derivação gastric em y-de-roux. Rev Col Bras Cir. 2010 Ago; 38(4): 232-36.

29. White S, Brooks E, Jurikova L, Stubbs RS. Long-term outcomes after gastric bypass. Obes Surg. 2005 Fev; 15(2): 155-63. doi: 10.1381/0960892053268282.

30. Xanthakos SA. Nutritional deficiencies in obesity and after bariatric surgery. Pediatr Clin North Am. 2009 Out; 56(5): 1105-21. doi: 10.1016/j.pcl.2009.07.002. 